\title{
Biological and Biochemical Characterization of Novel Lipid-like Antibacterial Substances (Mutalipocins) Produced by Streptococcus mutans Strain 32K
}

\author{
By TOMOKO KURITA* AND MASATOMO HIRASA WA \\ Department of Microbiology, Nihon University School of Dentistry at Matsudo, Matsudo, \\ Chiba-ken 27I, Japan
}

(Received 9 April 1987; revised 7 July 1987)

Two novel antibacterial substances (designated mutalipocins) have been isolated from the culture supernatant of Streptococcus mutans strain 32K (serotype $c$ ). The mutalipocins were purified by extraction of the culture supernatant with light petroleum (b.p. range $30-60{ }^{\circ} \mathrm{C}$ ), followed by Lobar column chromatography on Lichroprep RP-8. HPLC indicated that both mutalipocin preparations (ML-I and ML-II) were homogeneous. The $M_{\mathrm{r}}$ values of ML-I and ML-II were less than 1000 . Both mutalipocins were unaffected by treatment over the $\mathrm{pH}$ range $3 \cdot 0-10 \cdot 0$, or with phospholipase A or proteolytic enzymes, but were partially inactivated by treatment with lipase or phospholipase C. ML-II was resistant to heat treatment. TLC indicated that ML-I and ML-II contained unsaturated, aldehyde and/or ketone, and ester groups. The inhibition of $S$. mutans by ML-I and ML-II was due to bactericidal, rather than bacteriostatic, activities. The antibacterial spectra of ML-I and ML-II were narrower and more speciesspecific than those of bacteriocins produced by other Gram-positive bacteria.

\section{INTRODUCTION}

Streptococcus mutans is the principal etiological agent of dental caries (Hamada \& Slade, 1980). Many strains of $S$. mutans produce bacteriocins which inhibit the growth of the same or closely related species (Delisle, 1975; Fukushima et al., 1982; Hamada \& Ooshima, 1975; Ikeda et al., 1982; Paul \& Slade, 1975; Rogers, 1972). Early studies on the bacteriocins of S. mutans suggested that their production was affected by the culture conditions (Kelstrup \& FunderNielsen, 1977) and that their chemical and biological properties differ among strains. Several investigators (Ikeda et al., 1982; Hillman et al., 1984; Fukushima et al., 1982) have reported that bacteriocins produced by $S$. mutans are proteins. Recently, two novel lipid-like antibacterial substances were found in the culture supernatant of $S$. mutans 32K (serotype $c$ ) in our laboratory, and named mutalipocins. This study reports the isolation and purification of mutalipocins, and their biological and biochemical properties.

\section{METHODS}

Bacterial strains and media. The mutalipocin producing strain $S$. mutans 32K (serotype $c$ ) was isolated from human dental plaque. A laboratory stock culture of Streptococcus sobrinus 6715 (serotype $g$ ) was used as an indicator strain for assaying the activity of mutalipocin. Other bacteria used in this study are listed in Table 1 . Stock cultures of each strain were maintained at $4{ }^{\circ} \mathrm{C}$ on Brain Heart Infusion (BHI; Difco) agar containing excess $\mathrm{CaCO}_{3}$. The partially defined medium M4 (Fukushima et al., 1981) containing $0.05 \%$ (v/v) Tween 80 was used for the production of mutalipocin.

Screening strains of the $S$. mutans group for mutalipocin production. Mutalipocin production was assayed by the overlay procedure of Fredericq (1957). Strains of $S$. mutans were grown in BHI broth for $18 \mathrm{~h}$ at $37^{\circ} \mathrm{C}$ and $0.1 \mathrm{ml}$ of an appropriate dilution of this culture was seeded onto mitis-salivarius (MS) agar (Difco). After anaerobic incubation for $18 \mathrm{~h}$ at $37^{\circ} \mathrm{C}$, the plates were overlaid with the same agar containing the indicator strain $S$. sobrinus 6715. Following incubation of the plates for an additional $24 \mathrm{~h}$, the zone of inhibition surrounding the indicator strain was measured. 
Mutalipocin assay. Mutalipocin activity was determined by using a modification of the method of Hayes et al. (1983). A BHI agar plate was overlaid with $100 \mu$ l of a suspension of exponential-phase cells of S. sobrinus 6715 $\left(\mathrm{OD}_{540}=1 \cdot 0\right)$. Test culture supernatants and mutalipocin preparations were serially diluted in $0.01 \mathrm{M}$-sodium phosphate buffer ( $\mathrm{pH} 7 \cdot 2)$ and light petroleum (b.p range $\left.30-60^{\circ} \mathrm{C}\right)$, respectively, and samples $(10 \mu \mathrm{l})$ were placed in duplicate into wells in the agar plates. After $18 \mathrm{~h}$ incubation at $37^{\circ} \mathrm{C}$, the diameter of the zone of inhibition of the indicator organism around each well was measured. The log of mutalipocin concentration was proportional to the diameter of the inhibitory zone. Mutalipocin activity was expressed as arbitrary units (U) $\mathrm{ml}^{-1}$. The number of mutalipocin $\mathrm{U} \mathrm{ml}^{-1}$ was defined as the reciprocal of the highest dilution of supernatant that gave a clear zone of inhibition of $S$. sobrinus 6715 cell growth according to the method of Dajani et al. (1976).

Purification. The crude mutalipocin was initially extracted from 3 litres of culture medium by the Folch method (Folch et al., 1951). S. mutans $32 \mathrm{~K}$ was grown aerobically for $18 \mathrm{~h}$ at $30^{\circ} \mathrm{C}$ in $\mathrm{M} 4$ medium containing $0 \cdot 05 \%(\mathrm{v} / \mathrm{v})$ Tween 80 . The culture supernatant, obtained after centrifugation $\left(12000 \mathrm{~g}, 10 \mathrm{~min}, 4^{\circ} \mathrm{C}\right)$, was evaporated to dryness at room temperature under reduced pressure and the extract homogenized with 10 parts chloroform/methanol $(2: 1, \mathrm{v} / \mathrm{v})$. The homogenate was centrifuged at $1500 \mathrm{~g}$ for $10 \mathrm{~min}$, and the extract was collected, mixed with $0.5 \%(\mathrm{v} / \mathrm{v}) \mathrm{NaCl}$ in the ratio $1: 10$ and stored overnight at $4{ }^{\circ} \mathrm{C}$. After gentle removal of the upper aqueous layer, the clear chloroform phase was recovered. The remaining chloroform extract at the interface and in the aqueous layer was recovered by mixing with an equal volume of chloroform. The chloroform extracts were combined and concentrated under reduced pressure. The residue was treated with distilled water/n-hexane $(1: 1, \mathrm{v} / \mathrm{v})$; and then the same volume of light petroleum was added to the aqueous layer. The extraction procedure was repeated three times. Following removal of the gelatinous Tween 80 from the light petroleum layer, the remaining light petroleum layer was evaporated to a small volume. Of this material, $5 \mathrm{ml}$ (crude mutalipocin) was then applied to a Lobar column containing Lichroprep RP-8 prepared in methanol/water $(90: 10, \mathrm{v} / \mathrm{v})$. The column was eluted with the same solvent under low pressure and the eluate was monitored for absorbance at $254 \mathrm{~nm}$. The position of the peak with mutalipocin activity coincided with that of the UV absorbance peak. The active fractions were pooled, lyophilized and then reapplied to a Lobar column containing Lichroprep RP-8 prepared in methanol/water $(80: 20, \mathrm{v} / \mathrm{v})$. The column was eluted using the same solvent under low pressure. Two active fractions, which were designated ML-I and ML-II, were obtained by the above process.

Analytical methods. Analytical reverse-phase HPLC (RP-HPLC) was done with a model 510 liquid chromatograph fitted with a $254 \mathrm{~nm}$ wavelength detector (Waters). The column used was a Lichrosorb RP-8 ( $4 \times 200 \mathrm{~mm}$, Merck). Analytical TLC was performed on Kiesel gel $60 \mathrm{~F}_{254}$ (Merck) with chloroform/methanol/ ammonia $\left(60: 35: 8\right.$, by vol.) and on RP-8 $\mathrm{F}_{254}$ with methanol/water $(85: 15, \mathrm{v} / \mathrm{v})$. Standard lipids were used for comparison. ML-I and ML-II were also recognized by detecting the spots under UV light ( $254 \mathrm{~nm})$. Lipids were detected on TLC plates using the following reagents: non-specific lipids - $I_{2}$ (Barrett, 1962); phospholipids Dittmer (Dittmer, 1964); choline - Dragendorff (Beiss, 1964); glycolipids - $\alpha$-naphthol/ $\mathrm{H}_{2} \mathrm{SO}_{4}$ (Jacin \& Mishkin, 1965); amino phosphatides - ninhydrin (Fahmy et al., 1961); steroids - Zactis (Lowry, 1968); unsaturated groups $\mathrm{OsO}_{4}$; carbonyl groups - 2,4-dinitrophenylhydrazine (Skipski \& Barclay, 1969); esters - hydroxylamine hydrochloride (Skidmore \& Entenman, 1962). The $M_{\mathrm{r}}$ range of ML-I and ML-II was determined by the method of Ikeda et al. (1982). ML-I and ML-II solutions (1 ml) were placed onto sterile ultrafiltration membranes (Toyo; $M_{\mathrm{r}}$ cut off at $10000,5000,1000$ and 500 ) laid on M4 semisolid medium seeded with $S$. sobrinus 6715 . After $18 \mathrm{~h}$ of incubation at $37^{\circ} \mathrm{C}$, the diameter of the zone of inhibition was measured.

Bactericidal effect. S. sobrinus 6715 was grown for $18 \mathrm{~h}$ at $37^{\circ} \mathrm{C}$ in $\mathrm{M} 4 \mathrm{medium}$. The cells were collected, washed three times with $\mathrm{NaCl}$ and suspended to an $\mathrm{OD}_{540}$ of $1 \cdot 0$. Samples $(5 \mu \mathrm{l})$ of the cell suspension were added to $5 \mathrm{ml}$ $0.05 \mathrm{M}$-Tris $/ \mathrm{HCl}, \mathrm{pH} 7 \cdot 0$, containing $100 \mu \mathrm{g} \mathrm{ML}-\mathrm{I} \mathrm{ml} \mathrm{l}^{-1}$ or $50 \mu \mathrm{g} \mathrm{ML}-\mathrm{II} \mathrm{m} \mathrm{m}^{-1}$. The mixtures were incubated for 15 , 30,45 and $60 \mathrm{~min}$ at $37^{\circ} \mathrm{C}$, and then samples of the mixtures were immediately diluted and spread on BHI agar plates. The number of c.f.u. was counted after overnight incubation at $37^{\circ} \mathrm{C}$.

Method for assessing antibacterial activity. Sterile solutions containing various concentrations of ML-I and ML-II were prepared in light petroleum. From each solution, $10 \mu \mathrm{l}$ of material was taken and carefully spotted onto a BHI agar plate seeded with $5 \times 10^{5} \mathrm{c}$.f.u. of the test strain as described for the mutalipocin assay. After $18 \mathrm{~h}$ incubation at $37^{\circ} \mathrm{C}$, the diameter of the zone of inhibition was measured. Mutalipocin activity was expressed as the minimum inhibitory concentration (MIC) for test strains.

Chemicals. Lipase, phospholipase A, phospholipase C and phospholipase D were obtained from Sigma. Lichroprep RP-8 and Lichrosorb RP-8 were from Merck.

\section{RESULTS}

\section{Mutalipocin production}

Out of 192 human clinical isolates of $S$. mutans, $50(26 \%)$ demonstrated antibacterial activity by the overlay procedure and the supernatant of $S$. mutans $32 \mathrm{~K}$ formed the clearest and widest zone of inhibition against $S$. sobrinus 6715 . 


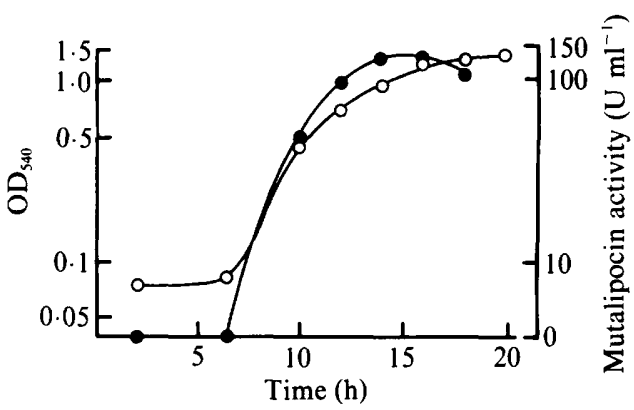

Fig. 1. Growth curve of $S$. mutans $32 \mathrm{~K}$ and the secretion of mutalipocin activity. $\bigcirc$, Cell growth $\left(\mathrm{OD}_{540}\right)$ at $30^{\circ} \mathrm{C}$ in $\mathrm{M} 4$ medium; the minimum generation time was $80 \mathrm{~min}$. $\mathrm{O}$, Mutalipocin activity, determined as described in Methods.

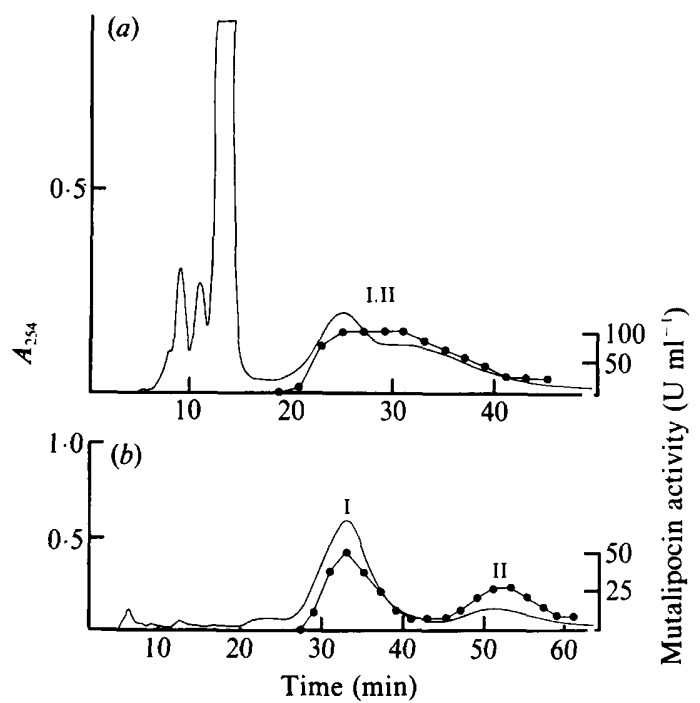

Fig. 2. Lobar column chromatography of crude mutalipocin. Crude mutalipocin was applied on a column $(10 \times 240 \mathrm{~mm})$ of Lichroprep RP-8 (size A) at room temperature, a flow rate of $2.0 \mathrm{ml} \mathrm{min}^{-1}$ and a pressure of $1.2 \mathrm{~kg} \mathrm{~cm}^{-2}$. The eluate was monitored at $254 \mathrm{~nm}$. The mobile phase consisted of methanol/water $(90: 10, \mathrm{v} / \mathrm{v})(a)$ or methanol/water $(80: 20, \mathrm{v} / \mathrm{v})(b)$. Mutalipocin activity $(O)$ is expressed as $\mathrm{U} \mathrm{ml}^{-1}$.

Optimal production of mutalipocin was obtained when $S$. mutans $32 \mathrm{~K}$ was grown aerobically in M4 medium at $30^{\circ} \mathrm{C}$; the addition of $0.05 \%$ Tween 80 to the culture medium gave 10 -fold higher amounts of mutalipocin (data not shown). The secretion of mutalipocin into M4 medium was dependent upon the phase of bacterial growth (Fig. 1). Mutalipocin continued to accumulate in the culture medium during the exponential phase, and the greatest amount of mutalipocin was present during the late-exponential phase of growth. Thus, for optimal production of mutalipocin, the cultures were grown to the late exponential phase $\left(\mathrm{OD}_{540}=1 \cdot 3\right)$. Although a small amount of mutalipocin was found in the cell fractions after disruption of the cells, its activity was very weak.

\section{Purification of mutalipocin}

Crude mutalipocin extracted from the culture supernatant of $S$. mutans $32 \mathrm{~K}$ was passed through a Lichroprep RP-8 Lobar column using methanol/water (90:10, v/v) as eluant (Fig. 2a). Highly polar materials were not retained in the column, while the antibacterial agent eluted after 


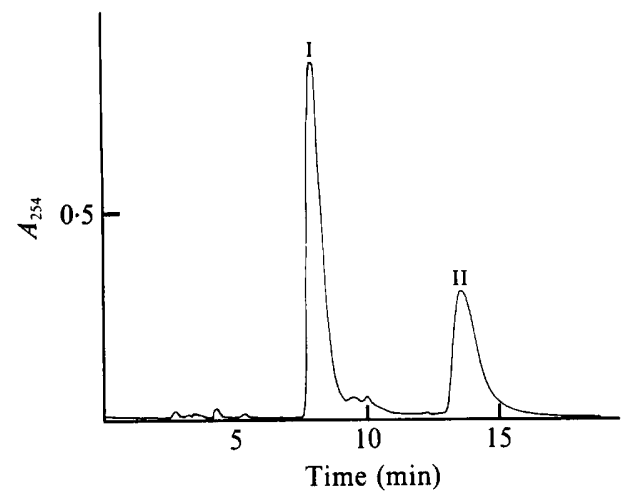

Fig. 3

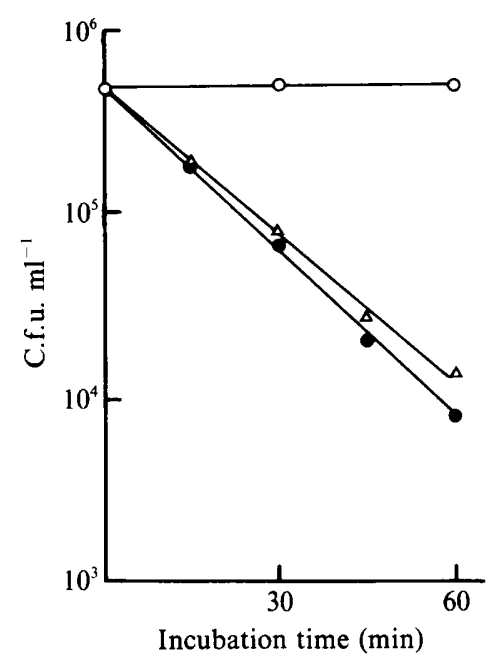

Fig. 4

Fig. 3. Separation of ML-I and ML-II by HPLC. Active fractions that were pooled after Lobar column chromatography were applied on a column $(4 \times 200 \mathrm{~mm})$ of Lichrosorb RP-8 (size A) at room temperature and at a flow rate of $1.0 \mathrm{ml} \mathrm{min}^{-1}$ and a pressure of $150 \mathrm{~kg} \mathrm{~cm}^{-2}$. The eluate was monitored at $254 \mathrm{~nm}$. The mobile phase consisted of methanol $/ 3 \%(\mathrm{v} / \mathrm{v})$ aqueous triethylamine, $\mathrm{pH} 3 \cdot 0(75: 25$, $\mathrm{v} / \mathrm{v})$.

Fig. 4. Bactericidal effect of purified ML-I and ML-II on cells of $S$. sobrinus 6715. $\bigcirc$, Control (no

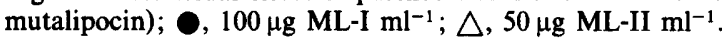

$20 \mathrm{~min}$ as a broad-shouldered peak. The active fractions were pooled, concentrated and rechromatographed on the same column using a different methanol/water ratio $(80: 20, \mathrm{v} / \mathrm{v})$ for elution (Fig. 2b). Two peaks were obtained, designated ML-I and ML-II; both exhibited mutalipocin activity, with ML-II showing twofold higher activity than ML-I. Further analysis of the fractions on a Lichrosorb HPLC using methanol $/ 3 \%(\mathrm{v} / \mathrm{v})$ aqueous triethylamine, $\mathrm{pH} 3 \cdot 0$ $(75: 25, \mathrm{v} / \mathrm{v})$ also revealed two distinct peaks (Fig. 3).

The purified ML-I was stable, but ML-II lost antibacterial activity during storage in light petroleum at $4{ }^{\circ} \mathrm{C}$ for several months. The addition of an antioxidizing agent (butylated hydroxytoluene) in light petroleum did not prevent the loss of activity. The yields of purified ML-I and ML-II from 31 of culture were $500 \mu \mathrm{g}$ and $100 \mu \mathrm{g}$, respectively. The specific activities of ML-I and ML-II were 2000 and $8000 \mathrm{U} \mathrm{mg}^{-1}$ respectively.

The $M_{\mathrm{r}}$ range of the mutalipocins was estimated by membrane exclusion since it was shown that the activity as determined by the diameter of the clear zone was proportional to the pore size of the membranes. More than $80 \%$ of the activity of ML-I and ML-II was retained by using membranes that excluded molecules of $M_{\mathrm{r}}$ larger than 1000, but the activity was not retained by using membranes that excluded molecules of $M_{\mathrm{r}}$ larger than 500 . These results indicated that the $M_{\mathrm{r}}$ range of these mutalipocins was between 500 and 1000 .

\section{Bactericidal effect}

The kinetics of cell killing by ML-I and ML-II are shown in Fig. 4. Treatment of $S$. sobrinus 6715 grown to exponential phase with either ML-I or ML-II decreased the number of c.f.u. The data show that ML-I and ML-II have bactericidal rather than merely bacteriostatic effects. The shape of the plots in Fig. 4 is consistent with single-hit kinetics for the killing of S. sobrinus 6715 by ML-I and ML-II.

\section{Sensitivities of various bacteria to $M L-I$ and $M L-I I$}

Various genera were tested for their sensitivities to purified ML-I and ML-II (Table 1). The antibacterial activities of ML-I and ML-II were greater against most strains of streptococci 
Table 1. Relative antibacterial activity of mutalipocins $M L-I$ and $M L-I I$ extracted from $S$. mutans strain $32 \mathrm{~K}$

Indicator strain

Streptococcus cricetus OMZ-61 (a)*

Streptococcus rattus BHT $(b)^{*}$

Streptococcus mutans PS-14 (c)*

Streptococcus mutans LM-7 $(e)^{*}$

Streptococcus mutans OMZ175 $(f)^{*}$

Streptococcus sobrinus B-13 $(d)^{*}$

Streptococcus sobrinus $6715(\mathrm{~g})^{*}$

Streptococcus salivarius HHT

Streptococcus sanguis ATCC 10556

Streptococcus mitis ATCC 9811

Streptococcus faecium ATCC 6057

Streptococcus bovis ATCC 9809

Streptococcus lactis ATCC 19435

Streptococcus pyogenes 703

Lactobacillus casei ATCC 7469

Actinomyces viscosus ATCC 19246

Actinomyces naeslundii ATCC 12104

Streptococcus aureus ATCC 13709

Escherichia coli $\mathrm{K} 12$

Klebsiella pneumoniae NUD

$\overbrace{\text { ML-I }}^{\text {MIC }\left(\mu \mathrm{g} \mathrm{ml}^{-1}\right)}$

$\begin{array}{cc}1 \cdot 0 & 0 \cdot 1 \\ 1 \cdot 0 & 0 \cdot 1 \\ 2 \cdot 0 & 0 \cdot 1 \\ 2 \cdot 0 & 0 \cdot 5 \\ 2 \cdot 0 & 0 \cdot 2 \\ 4 \cdot 0 & 1 \cdot 0 \\ 1 \cdot 0 & 0 \cdot 2 \\ 0 \cdot 5 & 0 \cdot 1 \\ 0 \cdot 8 & 0 \cdot 1 \\ 2 \cdot 0 & 0 \cdot 2 \\ 2 \cdot 0 & 0 \cdot 2 \\ 2 \cdot 0 & 0 \cdot 2 \\ 1 \cdot 0 & 0 \cdot 1 \\ 8 \cdot 0 & 4 \cdot 0 \\ 8 \cdot 0 & 4 \cdot 0 \\ 8 \cdot 0 & 4 \cdot 0 \\ 8.0 & 2 \cdot 0 \\ >100 & 8 \cdot 0 \\ >100 & >50 \\ >100 & >50\end{array}$

* Serotype of the $S$. mutans group.

(except for $S$. pyogenes), including seven serotypes of the $S$. mutans group, than against strains of Lactobacillus casei, Actinomyces viscosus and Actinomyces naeslundii, and that they were ineffective against the strains of Staphylococcus aureus (ML-I only), Escherichia coli and Klebsiella pneumoniae.

\section{Properties of $M L-I$ and $M L-I I$}

The characteristics of ML-I and ML-II are summarized in Table 2. The activities of ML-I and ML-II were not affected by $\mathrm{pH}$ over the range $3 \cdot 0-10 \cdot 0$ at $30^{\circ} \mathrm{C}$ for $1 \mathrm{~h}$, but both activities were lost during storage at $\mathrm{pH} 2 \cdot 0$. ML-I, unlike ML-II, was partially inactivated by storage at $\mathrm{pH} 11.0$. The activity of ML-I was reduced by heating at $100^{\circ} \mathrm{C}$ for $30 \mathrm{~min}$ and at $121^{\circ} \mathrm{C}$ for $30 \mathrm{~min}$, but ML-II was not affected by these treatments. The activities of ML-I and ML-II were not influenced by phospholipase $\mathrm{A}$, but were slightly affected by lipase and phospholipase $\mathrm{C}$. ML-II, but not ML-I, was partially affected by phospholipase D. The activities of ML-I and ML-II were not affected by proteolytic enzymes such as trypsin and pronase (data not shown). These results suggested that ML-I and ML-II might be phospholipids, but they differed from any of the commercial phospholipids tested. Table 3 shows the $R_{F}$ values of ML-I and ML-II on TLC in comparison with other lipid standards. Under the conditions used, ML-I and ML-II were differentiated from other lipid standards including phospholipids. The spots of ML-I and ML-II on TLC were positive with $\mathrm{I}_{2}, \mathrm{OsO}_{4}, 2$,4-dinitrophenylhydrazine and hydroxylamine hydrochloride, but were negative with the Dittmer, Dragendorff, $\alpha$-naphthol $/ \mathrm{H}_{2} \mathrm{SO}_{4}$, ninhydrin and Zactis reagents. These results indicate that ML-I and ML-II contain unsaturated, carbonyl and ester groups. ML-I and ML-II were freely soluble in methanol, acetone and light petroleum, but insoluble in chloroform and water.

\section{DISCUSSION}

It is well known that many strains of $S$. mutans produce antibacterial substances, so-called bacteriocins, which are also produced by a variety of Gram-positive and Gram-negative bacteria. For example, Ikeda et al. (1982) have purified a bacteriocin from $S$. mutans C 3603 
Table 2. Properties of the mutalipocins $M L-I$ and $M L-I I$ extracted from $S$. mutans strain $32 K$

The percentages in parentheses represent the residual activity compared to the control.

\begin{tabular}{|c|c|c|}
\hline \multirow[b]{2}{*}{ Property } & \multicolumn{2}{|c|}{ Response by: } \\
\hline & ML-I & ML-II \\
\hline $\begin{array}{l}\mathrm{pH} \text { stability (aqueous solution } \\
\mathrm{pH} 2 \cdot 0 \\
\mathrm{pH} 3 \cdot 0-10 \cdot 0 \\
\mathrm{pH} 11 \cdot 0\end{array}$ & $\begin{array}{l}\text { Labile }(25 \%) \\
\text { Stable }(100 \%) \\
\text { Labile }(50 \%)\end{array}$ & $\begin{array}{l}\text { Labile }(25 \%) \\
\text { Stable }(100 \%) \\
\text { Stable }(100 \%)\end{array}$ \\
\hline $\begin{array}{l}\text { Heat stability (aqueous solutic } \\
100^{\circ} \mathrm{C}, 30 \mathrm{~min} \mathrm{pH} 7.0 \\
121{ }^{\circ} \mathrm{C}, 30 \mathrm{~min} \mathrm{pH} 7.0\end{array}$ & $\begin{array}{l}\text { Labile }(50 \%) \\
\text { Labile }(37 \%)\end{array}$ & $\begin{array}{l}\text { Stable }(100 \%) \\
\text { Stable }(100 \%)\end{array}$ \\
\hline $\begin{array}{l}\text { Enzyme treatment } \\
\text { Lipase (pH 7.0) } \\
\text { Phospholipase A (pH 8.0) } \\
\text { Phospholipase C (pH 6.6) } \\
\text { Phospholipase D (pH 6.0) }\end{array}$ & $\begin{array}{l}\text { Labile }(80 \%) \\
\text { Stable }(100 \%) \\
\text { Labile }(90 \%) \\
\text { Stable }(100 \%)\end{array}$ & $\begin{array}{l}\text { Labile }(84 \%) \\
\text { Stable }(100 \%) \\
\text { Labile }(50 \%) \\
\text { Labile }(50 \%)\end{array}$ \\
\hline
\end{tabular}

Table 3. $R_{F}$ values of the mutalipocins $M L-I$ and $M L-I I$ extracted from $S$. mutans strain $32 K$ and of lipid standards on TLC plates

\begin{tabular}{lcc}
\multicolumn{1}{c}{ Substance } & $R_{F}{ }^{*}$ & $R_{F}{ }^{\dagger}$ \\
ML-I & 0.76 & 0.40 \\
ML-II & 0.73 & 0.30 \\
Sphingomyelin & 0.85 & 0 \\
Phosphatidylcholine & 0.82 & 0 \\
Ganglioside & 0.02 & 0 \\
Phosphatidylethanolamine & 0.88 & 0 \\
Cholesterol & 0.95 & 0.45 \\
Oleic acid & 0.80 & 0.08 \\
Linoleic acid & 0.87 & 0.08 \\
Linolenic acid & 0.93 & 0.08 \\
* Developed in chloroform/methanol/ammonia $(60: 35: 8$, by vol. $)$ on Kiesel gel $60 \mathrm{~F}_{254}$. \\
† Developed in methanol/water $(85: 15, \mathrm{v} / \mathrm{v})$ on $\mathrm{RP}-8 \mathrm{~F}_{254}$.
\end{tabular}

(serotype $c$ ) culture supernatant which has an $M_{\mathrm{r}}$ of approximately 4800 and which exhibits a narrow antibacterial spectrum. Fukushima et al. (1982) have also reported an extracellular bacteriocin from $S$. mutans RM-10 of unknown serotype with an $M_{\mathrm{r}}$ of approximately 973000 . Hillman et al. (1984) have isolated a low- $M_{\mathrm{r}}$ cell-free bacteriocin from $S$. mutans JH 1000 (serotype $c$ ) with a broad antibiotic spectrum.

In this paper, we have reported the purification of a new type of antibacterial substance (mutalipocin) from the culture supernatant of $S$. mutans 32K (serotype $c$ ), which has different characteristics when compared to bacteriocins. Mutalipocins are lipid-like, low- $M_{\mathrm{r}}$ substances which are soluble in organic solvents. No protein, carbohydrate or phosphorus could be detected in the purified mutalipocins.

Mutalipocins were optimally secreted from cells during the late exponential phase of growth, and the amount present in the medium decreased during the stationary phase. It is possible that mutalipocins could be adsorbed onto cells during the late stationary phase of cell growth. Although mutalipocins are stable physico-chemically, their purification was difficult because of the very low amounts excreted. Mutalipocins have a narrower species-specific spectrum of antibacterial activity than do the bacteriocins produced by $S$. mutans and other Gram-positive bacteria (Tagg et al., 1976), but they act bactericidally on the susceptible indicator cells in a manner similar to the bacteriocins reported by Delisle (1975) and Paul \& Slade (1975). 
Some unsaturated fatty acids, such as linoleic acid and linolenic acid, are known to inhibit the growth of $S$. aureus and $S$. mutans, and their effectiveness is related both to the degree of unsaturation and to the configuration of the molecule about double bonds (Butcher et al., 1976; Fukui et al., 1980). Carson \& Daneo-Moore (1980) also demonstrated that the unsaturated fatty acids oleic and linoleic acid induce lysis of Streptococcus faecalis, while saturated fatty acids have little or no effect. Although none of the commercial unsaturated fatty acids or phospholipids that we examined were identical to mutalipocin, it is possible that unsaturated groups in mutalipocin may contribute to antibacterial activity as a result of their auto-oxidation.

Mutalipocins have promising possibilities for the prevention of dental caries induced by $S$. mutans, since they have antibacterial activity. In addition, neither mutalipocin is inactivated by proteolytic enzymes or $\mathrm{pH}$, suggesting that mutalipocins may retain their activities in the complex environment of the oral cavity, with contains many different proteolytic enzymes (Nord et al., 1969; Yoshimura et al., 1984). We are currently investigating the mutalipocin producing $S$. mutans strain $32 \mathrm{~K}$ in vivo and in vitro for its ability to invade dental plaque and to replace the indigenous flora.

We express our thanks to Drs T. Ikeda and S. M. Michalek for helpful advice on this manuscript. This study was in part supported by the Scientific Research Fund of the Ministry of Education, Japan.

\section{REFERENCES}

BARRETT, G. C. (1962). Iodine as a 'non-destructive' colour reagent in paper- and thin-layer chromatography. Nature, London 194, 1171-1172.

BEISS, U. (1964). Zur papierchromatographischen Auftrennug von Pflanzenlipiden. Journal of Chromatography 13, 104-110.

BUTCHER, G. W., KING, G. \& DYKE, K. G. H. (1976). Sensitivity of Staphylococcus aureus to unsaturated fatty acid. Journal of General Microbiology 94, 290296.

Carson, D. D. \& Daneo-Moore, L. (1980). Effects of fatty acids on lysis of Streptococcus faecalis. Journal of Bacteriology 141, 1122-1126.

DaJani, A. S., TOM, M. C. \& LAw, D. J. (1976). Viridins, bacteriocins of alpha-hemolytic streptococci : isolation, characterization and partial purification. Antimicrobial Agents and Chemotherapy 9, 8188.

DelisLe, A. L. (1975). Production of bacteriocin in a liquid medium by Streptococcus mutans. Antimicrobial Agents and Chemotherapy 8, 707-712.

DitTMer, J. C. \& Lester, R. L. (1964). A simple, specific spray for the detection of phospholipids on thin-layer chromatograms. Journal of Lipid Research 5, 126-127.

Fahmy, A. R., Niederwieser, A., Pataki, G. \& BRENNER, M. (1961). Dunnschicht-chromatographie von Aminosauren auf Kieselgel G. Helvetica chimica acta 44, 2022-2026.

Folch, J., Ascoli, I., Less, M., Meath, J. A. \& LEBARON, F. N. (1951). Preparation of lipid extracts from brain tissue. Journal of Biological Chemistry 191, 833-841.

FredericQ, P. (1957). Colicins. Annual Review of Microbiology 11, 7-22.

Fukui, K., Miyake, Y., Kobayashi, K. \& Moriyama, T. (1980). Effects of various fatty acids on growth and water-insoluble glucan synthesis of Streptococcus mutans. Japanese Journal of Oral Biology 22, 465-469.

Fukushima, H., Fukushima, S., UMEmoto, T., Fukuhara, H. \& Sagawa, H. (1982). Purification and chemical analysis of a bacteriocin from the oral bacterium Streptococcus mutans RM-10. Archives of Oral Biology 27, 721-727.

Fukushima, K., Motoda, R. \& IKedA, T. (1981). Effects of exogenous insoluble glucan primer on insoluble glucan synthesis by Streptococcus mutans. Journal of Dental Research 60, 1707-1712.

Hamada, S. \& Ooshima, T. (1975). Production and properties of bacteriocin (mutacin) from Streptococcus mutans. Archives of Oral Biology 20, 641-648.

Hamada, S. \& Slade, H. D. (1980). Biology, immunology, and cariogenicity of Streptococcus mutans. Microbiological Reviews 44, 331-384.

hayes, T. J., Cundy, K. R., Fernandes, P. B. \& HOOBER, J. K. (1983). Purification and characterization of bacteriocin from Bacteroides fragilis. Journal of Bacteriology 155, 1171-1177.

Hillman, J. D., Johnson, K. P. \& YÄPHE, B. I. (1984). Isolation of a Streptococcus mutans strain producing a novel bacteriocin. Infection and Immunity 44, 141144.

IKeda, T., Iwanami, T., Hirasawa, M., Watanabe, C., McGhee, J. R. \& ShIota, T. (1982). Purification and certain properties of a bacteriocin from Streptococcus mutans. Infection and Immunity 35, 861-868.

JACIN, H. \& MishKIN, A. R. (1965). Separation of carbohydrates on borate-impregnated silica gel $\mathrm{G}$ plates. Journal of Chromatography 18, 170-173.

KelstruP, J. \& FunDER-NielSEN, T. D. (1977). Synthesis of bacteriocins on liquid cultures of Streptococcus mutans. Journal de biologie buccale $\mathbf{5}$, 99-106.

LOWRY, R. R. (1968). Ferric chloride spray detector for cholesterol and cholesteryl esters on thin-layer chromatograms. Journal of Lipid Research 9, 397.

Nord, C. E., Frostell, G. \& Soder, P. O. (1969). A comparison between proteolytic enzymes in dental 
plaque material from children and adults. Svensk tandläkare tidskrift 62, 3-6.

Paul, D. \& Slade, H. D. (1975). Production and properties of an extracellular bacteriocin from Streptococcus mutans bactericidal for group A and other streptococci. Infection and Immunity 12, 13751385.

Rogers, A. H. (1972). Effects of the medium on bacteriocin production among strains of Streptococcus mutans. Applied Microbiology 24, 294-295.

SKIDMORE, W. D. \& ENTENMan, C. (1962). Twodimensional thin-layer chromatography of rat liver phosphatides. Journal of Lipid Research 3, 471-475. SKIPSKI, V. P. \& BARClaY, M. (1969). Thin-layer chromatography of lipids. Methods in Enzymology 14, 530-598

TagG, J. R., Dajani, A. S. \& Wannamaker, L. W. (1976). Bacteriocins of Gram-positive bacteria. Bacteriological Reviews 40, 722-756.

Yoshimura, F., Nishikata, M., Suzuki, T., Hoover, C. I. \& NewbRUN, E. (1984). Characterization of a trypsin-like protease from the bacterium Bacteroides gingivalis isolated from human dental plaque. Archives of Oral Biology 29, 559-564. 